\title{
Legal Profession in Major Legal System
}

\section{Suman Acharya, PhD}

Email: sumanacharaya@gmail.com

Submission Date: June 07, 2021.

\begin{abstract}
Legal education and profession are interconnected issues. Each and every country of the world set minimum academic qualification to become a lawyer, which is bachelor's degree in law. Then, they can participate in Bar Examination and successful candidate will get license with apprenticeship training. However, other superior degree is preferable. Legal education is considered as interdisciplinary and multidisciplinary issues. Curriculum of legal education is set in the same basis. In the context of legal profession, civil legal system prefers specialization of lawyer whereas common legal system accepts generalization in legal field. Socialist country prefers to impart communist doctrine for lawyer so that they can work for social justice and collective benefit. Nevertheless, Covid-19 has made hardest hit for the legal professional because of the lockdown and related situation. Employment of online system in case hearing system may resume their legal profession as usual even in crisis period.
\end{abstract}

Keywords: France, Germany, Japan, UK, USA, India, USSR, China, Nepal

\section{Introduction}

The educational prerequisite, the methods and quality of legal education to become a lawyer varies from country to country. Some countries require extensive clinical training in the form of apprenticeships as special clinical courses whereas much country doesn't have such compulsory provision of clinical training. Yet, clinical course can be the compulsory paper to impart case laws method in college level education. Bachelor's degree is the minimum qualification to be a legal professional. Higher the legal education higher level of research and advocacy skills will supposedly be developed. Legal Education is essentially a multi-disciplined and multipurpose 
education which can develop reasoning capacity of the legal professional and idealism needed to strengthen the legal system and society.

\section{General Design of Legal Education}

Generally, schooling of 12 years and LLB/BALLB course are the basic requirements to be legal professional. It may vary from country to country. In fact, LLB is accompanied by another bachelor's level degree. There can also be interdisciplinary and multidisciplinary course to impart wide varieties of knowledge so that a person can understand whole social system and their method of functioning. Additionally, Masters Degree and Ph.D. Degree are preferable degree. So, many countries have at least 2-5 years bachelors and two years of masters program in law. Legal education is interdisciplinary and multidisciplinary to fulfill the necessity of the society.

After the completion of Bachelor's Degree in Law, there is separate examination to get the license of legal professional. Under the British System, there are Senior Advocate, Barrister, and Solicitor as a legal professional whereas Advocate, Judge, Prosecutor, Bailiff, and Notary are the legal professionals for civil legal system. Same method of civil legal system is found in Socialist Legal System. Originally, there was the involvement of priest and the King in Hindu Legal System and Islamic Legal System. In fact, it was the practice of the world community.

Common Legal System and Socialist Legal System didn't have the practice of compulsory legal education to become a lawyer in early days. However, in later days, they set the qualification of Bachelor's Degree in Law. Roman Legal System prescribed the course of five years to become a successful legal professional and jurists. Knowledge of religion was compulsory in the justice delivery process under religious legal system.

\section{Legal Profession in Civil Legal System (I)}

Civil legal system prefers specialization in particular discipline. Legal professionals are referred to Advocate, Government Lawyer, Prosecutor, Notary and Judges etc. Judges and notary public receive similar training. Notary of civil legal system plays the role of local judge for petty issues. In Roman Legal System, 2000 books were summarized into 50 categories of book in Justinian Code. The course to study for 5 years was prescribed in Justinian Code. Gaius method was 
usually adopted with scholastic and neo-scholastic method. This tradition has been continued by Civil Legal System.

\section{(A) Legal Profession in France}

France established the tradition of 3 years Bachelors of Law Program (License de Droit) to be a lawyer. However, it varies from nature of the course. Additionally, there are 2 years of Masters of Law Program and 3 Years PhD Programs. After graduation in law, especially after the completion of 1st year LLM (4 years of legal education), prospective candidate has to obtain a Certificat d'Aptitude à la profession d'Avocat (CAPA). ${ }^{1}$ It is also known as bar exam. It consists of written exams first. After the success in written exam, there will be the oral exams. Degree from foreign country with equivalency is also allowed to participate in the exam. For foreign nationals it has separate provisions.

Then, 18 months course should be completed from law school as apprenticeship training, which is compulsorily required. Apprenticeship training consists of 6 months courses at the bar school with exams; 6 months internship abroad or in France in a law firm; 6 months course of law degree with report of case and 6 months internship in a law firm with report. In order to get accepted at the lawyer school, it is necessary to pass entrance exams at Centre Régional de Formation des Avocats (CRFPA). ${ }^{2}$ However, French Juristes (In-house Conunsel) doesn't require holding this license. Lawyers in France are ethically bound. ${ }^{3}$

Moreover, the notary is a public legal official appointed by order of the Minister of Justice. Notaries are also independent self-employed profession. They receive the training of the judges.

Professional judges in France are career judges. They are divided into adjudicating judges and contractual judges, who try law cases. The judges of the local courts were introduced by the Justice System Framework and Planning Act, 2002, supplemented by Act, 2005. They are

1 Professional Regulations. https://www.cnb.avocat.fr/en/professional-regulations-texts.

2 Conseil National des Barreaux. The Main Instruments of Legal Profession in France. (May 2014). http://encyclopedie.avocats.fr/GED_BWZ/197521391570/CNB-2014-06-00_aei_Textes-Profession-avocatLG-eNG(P).pdf.

3 Amendments to Law No. 71-1130 of December 31, 1971 reforming certain judicial and legal professions. (Articles 1 to 34). https://www.legifrance.gouv.fr/loda/id/JORFTEXT000000718250/. Law n ${ }^{\circ}$ 71-1130 of December 31, 1971 reforming certain judicial and legal professions. https://www.legifrance.gouv.fr/loda/id/JORFTEXT000000508793/. Decree n ${ }^{\circ}$ 91-1197 of November 27 , 1991 organizing the legal profession. https://www.legifrance.gouv.fr/loda/id/JORFTEXT000000356568/. 
appointed by order, with the assent of the Supreme Council of the Judiciary, for a term of seven years, which may not be renewed. There are also law officers who work for the State Counsel's Office. Also, there is the designation of Bailiff. The court bailiff is a public legal official appointed by order of the Minister of Justice. A bailiff is independent self-employed profession.

\section{(B) Legal Profession in Germany}

The first requires to study somewhere at a university and earn Bachelor's Equivalent Degree. Firstly, University Education of at least four years (generally it ranges from 6 to 12 semesters) is necessary. A person requires criminal law and other to be chosen as major subject. A person becomes a lawyer by passing two legal state exams. With or without university degree, a person participates in the first state exams consisting of 5-8 case studies and faces an oral exam also. The case study appears in the format of legal opinions. ${ }^{4}$ Then, they participate in Apprenticeship Training. It requires 2 years of practical training at courts, administration and law firms. After this training, Second State Exam is conducted. The exam is similar to the first exam; only major difference is that person writes court rulings and opinions on the possible outcome of court proceedings. Then, they will be eligible for getting bar work. The second examination provides a uniform qualification for all legal professions through State Examination System.

Both stages end with a state examination covering the entire scope of the law. After successfully passing both state examinations, the young lawyer is theoretically qualified to adopt any legal profession. Once license received they must be the member of the Local Bar Association. Germany encourages publishing thesis and their academic work and exercises. Every lawyer desires to get highest degree of law $(\mathrm{PhD})$ in Germany. ${ }^{5}$

\footnotetext{
4 To be an advocate in Germany, a person should go through formal education, first state exam, apprenticeship and second state exam. cpress.
} 
Germany classifies legal professional as Advocate, Notary, Judges, Prosecutor, Judicial Officer, Patent Agent, and Notary etc. Notary is appointed by Ministry of Justice. For Judges, Ministry of Justice of Lander regulates it in State Level. ${ }^{6}$

German Judges Act is used as principal legislation to regulate and control judgeship profession in national and regional courts. Legislation of Land level also prescribes the standard for it. The performance of judge in Lander level is supervised by the ministries of justice. Likewise, Federal Ministry supervises the performance of judges in federal courts. However, it doesn't supervise the performance of the judges of the Federal Constitutional Court. There are professional judges as career that serves either in national or in regional courts. Judges at Land level officiate in a local court, a regional court or a higher regional court. Most judges work at Land level.

In Germany Notaries generally need to have completed the same legal training as judges. They provide independent, impartial and objective advice and support for important legal transactions and the handling of legal matters in such a way as to avoid litigation. Their most important task is certifying legal transactions.

\section{(C) Legal Profession in Japan}

Japan acknowledges 2 to 3 years Bachelors Degree in law or other types of equivalent preliminary legal education, which varies from university to university. Japan follows Bolagna Standard in legal education and profession. It consists of first a license of law program: threeyear period (in 2004 JD Degree was introduced but became dysfunctional), Master of Law Program with Two-Year Period and Ph.D. in Law with Three-Year Period which may often more. Graduation with Bachelor's Degree or equivalent degree in law is necessary to become a lawyer in Japan. If there is no Bachelor's in law, qualifying exam for bar exam is necessary to participate in the Bar Examination. ${ }^{7}$

National Bar Examination which has been changed in 2006 recommended the examination of first paper with one day short answer question concerning the six laws i.e. administrative law; three papers with essay types long answer questions concerning public law, civil law and criminal law as well as subjects that is selected by the examinee and Internship. One year

6 Legal Profession in Germany. https://e-justice.europa.eu/content_legal_professions-29-deen.do?member $=1$.

7 Vide Attorney Act, 1949. http://www.mizogami.gr.jp/english/images/Attorney_Acts of Japan.pdf. 
internship is supervised by the Legal Research and Training Institute of the Supreme Court of Japan.

All bar examination participants must complete the course of graduation in law which normally consists of 2-3 years course, and are limited to taking the examination within five years after graduation. A person can attend only 3 times in five years in Bar Exam. After five years of the graduation, students cannot attend for the license. Fresh starts needed in education. Generally, education pattern of Japan consists of 6 Years Elementary School+3 Years Middle School+3 Years High School+4 Years University=16 Years of Education. Candidates who doesn't have graduation degree in law may participate in the bar examination after getting success in a preliminary qualifying examination. But getting success in this exam is still a minor path and most candidates are from law school background.

Japanese Bar Exam is one of the most difficult exam which gets success only of $20 \%$. Continuous legal education is compulsorily recommended in Japan. Foreign lawyer can get permission from Ministry of Justice ${ }^{8}$ and Japan Federation of Bar Association under Manual on Application for Approval \& Designation of Foreign Lawyer. ${ }^{9}$

After graduation in law, a person can enter for Bar Examination and successful candidate in Bar Examination participates in the apprenticeship training of 12 months in school, practical aspects, ethics and internship. It has been reduced from 2 years to 1 year's apprenticeship in 2006. One year internship is supervised by the Legal Research and Training Institute of the Supreme Court of Japan. Bar exam consists of 4 days exam. Successful students should take oath to work as a legal professional. ${ }^{10}$

$8 \quad$ Act on Special Measures concerning the Handling of Legal Services by Foreign Lawyers, 1986. https://www.nichibenren.or.jp/library/en/about/data/hls.pdf.

9 Information for Registered foreign lawyer. https://www.nichibenren.or.jp/en/about/judicial_system/gaiben_info.html. Also vide A Guide to Rules for Foreign Special Members. https://www.nichibenren.or.jp/library/en/about/data/guide.pdf. 
Japan accepts specialization in law viz. Attorney at law, Registered Attorney at Foreign Law, Notary Public, Administrative Scrivener, Judicial Scrivener, Certified Public Accountant, Certified Tax Accountant, Patent Attorney, Certified Social Insurance and Labor Consultant, Land and House Investigator etc. Foreign lawyer can get permission from Ministry of Justice and Japan Federation of Bar Association under Manual on Application for Approval \& Designation of Foreign Lawyer.

\section{Legal Profession in Common Legal System (II)}

\section{(A) Legal Profession in the UK}

Common law legal education is accepted in the course of law in England, Wales and Northern Ireland. However, Scotland accepts hybrid form of Common Law and Civil Law in legal education, which offers dual-qualifying degree and separate degree for each part of the country. A law degree is compulsory for legal profession and conversion course are also allowed. One year conversion course like Common Professional Examination or Graduate Diploma in Law is accepted in England and Wales.

After formal education, one year Legal Practice Course is necessary in Law Society ${ }^{11}$ of England and Wales for solicitor followed by two years apprenticeship course and One Year Bar Professional Training Course is necessary in Inns of Court for Barrister followed by one year apprenticeship. ${ }^{12}$ In Scotland Solicitor follows Law Society of Scotland and Advocates follow the Faculty of Advocates. In Scotland it is required LLB or honored degree and accelerated 2 years LLB.

Solicitor passes through 7-8 Years education and apprenticeship training i.e. 3 years under graduate law degree and in case other course one year conversion course; one year legal practice course and two years professional skills course and two years law training with law firm. Barrister requires passing through three year undergraduate degree, one Year Bar Professional Training Course and one Years Pupilage in Chambers which will be 5 years of legal education and training. ${ }^{13}$

11 The Law Society. https://www.lawsociety.org.uk/en.

12 Vide Bar Council. https://www.barcouncil.org.uk/.

13 Vide Suzanne Rab, Serle Court Chambers. Regulation of the legal profession in the UK (England and

Wales): overview. https://uk.practicallaw.thomsonreuters.com/7-633-

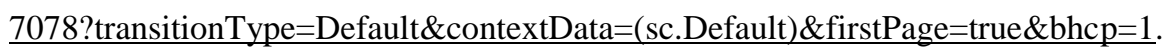


According to Court and Legal Service Act, 2007, Barrister is licensed under Bar Council in England and Wales and under Faculty of Advocates in Scotland. They should get professional membership of Barrister in the Honourable Society of Lincoln's Inn, the Honourable Society of the Inner Temple, the Honourable Society of the Middle Temple Inn and the Honourable Society of Gray's Inn. ${ }^{14}$

Moreover, Solicitor is licensed under Law Society under Solicitor Act, 1974. And, Senior Advocate (Senior Counsel/Queen's Counsel) is licensed under Queen's Council. Queen in the advice of the Lord Chancellor by making Panel appoints senior advocate in the UK. Courts and Legal Services Act 1990 has removed the monopoly of barristers to act as advocates and granting solicitors rights of audience in specified circumstances. It is replaced by Legal Service Act, 2007. ${ }^{15}$

\section{(B) Legal Profession in the USA}

Formal course in law is possible after graduation in some other discipline as a postgraduate course. To attend a US law school, a student must already hold at least an undergraduate degree. In order to practice as a lawyer in the US, many states require a candidate to have a Juris Doctor, a three-year degree, from a law school that has been approved by the American Bar Association. ${ }^{16}$ The American Bar Association's Council of the Section of Legal Education and Admissions to the Bar is recognized by the US Department of Education as the accrediting agency for professional JD programs. The Council monitors the accreditation standards. NonAmerican Bar Association accredited law schools may only qualify attendees to practice in the state in which the school is located; consequently, graduates of non-American Bar Association accredited schools often have difficulty being licensed to practice law in other states. The criteria for eligibility to take the bar examination or to otherwise qualify for bar admission are set by each state's bar association. There is virtually no oversight of legal education or law practice by the federal government. Therefore, it is important to choose a school in the state in which one wishes to take the bar exam and practice law.

So, the prequalification to be a lawyer in the USA is a student must already hold at least an undergraduate degree. The Law School Admission Test (LSAT), success in Juris Doctor (J.D.)

\footnotetext{
$14 \quad$ Inns of Court.

https://web.archive.org/web/20110701101529/http://www.barcouncil.org.uk/about/innsofcourt/. Legal Service Act, 2007. https://www.legislation.gov.uk/ukpga/2007/29/contents. Vide The American Bar Association. https://www.americanbar.org/about the aba/.
} 
Degree, experience of Participating in a Clerkship, and success in State Bar Examination is necessary. ${ }^{17}$ Five year practice of one State may allow to practice in another State. ${ }^{18}$

Lawyers have no classification in the USA although people prefer to call barrister and solicitor in common parlance. Yet, senior advocate status is granted by the Supreme Court or High Court in the USA. Some lawyers prefer to call senior counsel or attorney at law. Bar Exam is taken by each state. It consists of 3 days of examination. Some State i.e. Louisiana follows civil legal system. Education system is also dominated by the local laws. The legal profession of the USA has unique characteristics of legal professional, which are contingent fee, global network, listing in stock exchange, hourly basis of payment etc. There is a list of lawyers issued by law firm from which client selects lawyer. In the USA, every sector requires lawyer. Permission is required for foreign lawyer from concerned Bar Council if they want to represent the clients.

\section{(C) Legal Profession in India}

There are Central University, State University, Private University, Deemed University (UGC recognition) in India. Law course should be recognized by the Bar Council and UGC of India. Generally, India has 3 years LLB, 5 years Integrated Undergraduate Degree i.e. B Com. LLB, B SC LLB, BA LLB, BBA LLB etc. Bachelor's in Law is the prequalification to be a lawyer. After it, a candidate has to get success in Bar or Barrister Exam. Additionally, there are 2 years and 1 years LLM. India has also Integrated MBL LLM, MBA LLM etc. PhD Degree consists generally of 3 years.

After completion of graduation i.e. LLB/BA LLB, it is necessary to sit for All India Bar Examination (AIBE). After clearing examination, application has to be submitted in Council for a license. ${ }^{19}$ A person with license shall then be eligible to apply at bar of any court, like Supreme Court Bar Association (SCBA), Delhi HC Bar Association, etc. The Advocates Act of 1961 amended and consolidated the law relating to legal practitioners and provided for the constitution of the State Bar Councils and an All-India Bar as the Bar Council of India as superior

\footnotetext{
17 https://legalcareerpath.com/becoming-an-attorney/.

18 Vide Kendra L Basner, Wendy Wen Yun Chang, Cassidy E Chivers, Anthony E Davis, Noah D Fiedler and Janis M Meyer, Hinshaw \& Culbertson LLP. Regulation of the legal profession in the United States: overview. https://uk.practicallaw.thomsonreuters.com/2-633-

19 6340?transitionType $=$ Default \&contextData $=($ sc. Default $) \&$ firstPage $=$ true. Vide The Bar Council of India. http://www.barcouncilofindia.org/.
} 
authority. ${ }^{20}$ The Bar Council of India is comprised of the Attorney General of India and the Solicitor General of India as its ex officio members, as well as one member elected from each of the State Bar Councils. Solicitor system was removed in 1970's. The members of the State Bar Councils are elected for a period of five years. ${ }^{21}$

Notaries are appointed by central government or state government for whole or partial area from among the lawyer having 10 years experiences or from member of India Legal Service or central or state government having knowledge of law.

\section{Legal Profession in Socialist Country (III)}

\section{(A) Legal Profession in USSR}

USSR established socialist tradition of legal education and profession based on the philosophy of Karl Marx. In early time, it didn't have compulsory law education to be a lawyer in USSR but knowledge of communist philosophy was compulsory. Education system was highly centralized and indoctrinated of Marxist-Leninist Theory. Education system was Pre-School; 4 Years Elementary School; 3 or 4 Years Secondary School; and Five Year Diploma for Specialization etc. There was also Master's Degree and PhD degree in many disciplines. Lawyer as private practitioner was existed but they had to present real incidence before the court. All were the member of the state authority. In later days, law degree was introduced as special course of legal analysis. There were Advocates and Notaries in USSR System. ${ }^{22}$

\section{(B) Legal Profession in China}

In the first two decades after establishment of republic of socialist china, there was no university legal education. Previous law degree was quashed. New law faculties were opened at the end of 1970. Gradually, legal education was also flourished. Most judges and prosecutors did not have law degree. There is the education system i.e. 3 Years of Pre School; Primary Education of 6 Years; 3 Years Junior Middle School Education; 3 or 4 or 5 year Bachelor Program etc. At least, 3 years law program or equivalent bachelor's degree in law is necessary to be a lawyer

\footnotetext{
20 Advocates Act, 1961. https://uk.practicallaw.thomsonreuters.com/2-633$\underline{6340}$ ?transitionType $=$ Default $\&$ contextData $=($ sc. Default $) \&$ firstPage $=$ true.

21 Vide Bar Council Act, 1926. https://www.icj.org/wp-content/uploads/2014/03/Myanmar-Bar-Council-Actand-amendments-legislation-1926-eng.pdf.

22 Valeriya Kachura and Aleksandr Kuznetsov, Liniya Prava Law Firm. Regulation of the legal profession in the Russian Federation. https://uk.practicallaw.thomsonreuters.com/1-6338957? transitionType=Default\&contextData=(sc. Default $) \&$ firstPage=true $\& b h c p=1$.
} 
nowadays. It requires 2 years or more of experience in legal filed. Examination for practicing lawyer is taken place two times a year. One must first obtain a recognized degree (a bachelor's, master's, or doctoral degree), pass the National Judicial Examination, and complete a two-year apprenticeship.

There are part time practicing lawyers, government lawyers, in-house lawyers, and military lawyers as private practitioners. Notary is regulated by Ministry of Justice and cannot work in law firm. The fee of Notary is fixed rate or in percentage basis. In many aspects, there is not compulsory provision of notarization but it is preferable by the clients. Foreign lawyer cannot be requalify in China. They can establish representative office but they cannot represent in the court. Lawyer's fee is regulated by Ministry of Justice.

The Chinese National Lawyer's Association was established in Beijing in 1986. The Ministry of Justice in 1986 started to administer a Unified National Qualification Exam for lawyers. This examination system was replaced by the State Judicial Exam (SJE) in 2002. The Lawyers Law was enacted by the National People's Congress (NPC). The Ministry of Justice (MOJ) issued a notice urging every province, autonomous region and municipality to establish legal aid centers in 1996. A second notice was issued in 1997 and again National Legal Aid Regulations were adopted in 2003. It prescribed the roles of the legal aid centers, eligibility criteria for legal aid, and the application procedure to get approval for legal aid. ${ }^{23}$

\section{Legal Education and Profession in Nepalese Legal System (IV)}

Shresta Pathsala established in 1962 BS (1905 AD), which played vital role to produce early form of legal professional in Nepal. Knowledge of legal horizon expanded when Nepal Law College affiliated to Patna University of India in 2011 BS (1954 AD) to produce law graduates. It was replaced by Tribhuwan University in 2016 BS (1959 AD) under the entitlement of institute of law which was later converted into faculty of law in 2041 BS (1984 AD). There was phase-out of Proficiency Certificate Level in 2052 BS (1995 AD). After the launch of LLB and LL.M. program in 2053 BS (1996 AD) under the Faculty of law, numbers of students have got highly skilled legal knowledge.

23 Jing Li. The legal profession of China in a globalized world: innovations and new challenges. (11 July 2018). https://www.tandfonline.com/doi/full/10.1080/09695958.2018.1491853. 


\section{University for Legal Education in Nepal}

\section{- TU Constituent Campus:}

- Mahendra Multiple Campus, Dharan (LLB)

- Mahendra Bindeswori Multiple Campus, Rajbiraj (LLB)

- Nepal Law Campus, Kathmandu (LLB, BA LLB and 2 years LLM \& 3 years LLM)

- Butwal Multiple Campus, Butwal (LLB)

- Prithibi Narayan Multiple Campus, Pokhara (LLB and BA LLB)

- Mahendra Multiple Campus, Nepalganj (LLB)

- TU Affiliated Campus

- Harikhetan Multiple Campus, Birganj (LLB)

- National Law College, Sanepa (BA LLB and LLM)

- Purbanchal University Affiliated College

- Kathmandu School of Law

- Chakrabarti Habi Law College

- Bright Vision Law College, Biratnagar

- Faculty of Management and Law, Nepal Open University

Tribhuvan University and Purbanchal University have launched law program in their affiliated college as well. Purbachal University has given affiliation to teach 5 years LLB and 2 years LLM especially in Kathmandu School of Law in 2058 BS (2000 AD), Chakrabarti Law College in 2068 BS (2010 AD), and Bright Vision College of Biratnagar in 2068 BS (2010 AD). These institutions launched LLM (2 Years) as well as LLB (5 years).

Kathmandu University School of Law in 2070 BS (2013 AD) launched Bachelor of Business Management and Bachelor of Law (BBM LLB) and Masters by Research in Energy and Infrastructure Law (LLM). National Law College is affiliated with TU in 2069 BS (2012 AD), which has launched the program of Masters of law and 5 year BALLB program. Previously, there was sole monopoly of Nepal Law College which runs 2 years and 3 years Maser's in law program in 2070 BS (2013 AD) including 3 years LLB, and 5 years BALLB program. Additionally, 3 years LLB program is launched in different other constituent and affiliated college of various place of Nepal. Five years' $(2+3$ years proficiency certificate and diploma in law respectively) course was replaced by the two years' BL program during 1970s. In 1984 BS (2041 BS), the five years' semester-based course was abruptly changed. 
Section 16 of Court Procedure of Muluki Ain 1910 BS (1953 AD) provides for legal representative. Under Interim Government Act, 2007 BS (1951 AD), Supreme Court Act, 2008 BS (1952 AD) was enacted. Nepal Bar Association was established in 2013 BS (1956 AD). ${ }^{24}$ There were Senior Advocate, Advocate, Pleader and Agent under Legal Profession Act, 2025 BS (1968 AD). Nepal Bar Council Act, 2050 focused on Senior Advocate and Advocate. No Senior Advocate is appointed in the absence of Bachelor's degree in law. Recently, 7 years of job experience as pleader is required to participate in the Bar Exam for Advocate if they do not have Bachelor's Degree in Law. It means after the completion of Bachelor's Degree in Law, a candidate should participate in the examination of Nepal Bar Council. Successful candidate will start career as a lawyer after the training of Nepal Bar Council. ${ }^{25}$

Basically, Nepal Bar Council ${ }^{26}$ classifies legal professional as Senior Advocate, Advocate, Pleader and Agent. Senior Advocate is selected from among senior practicing lawyers by the full court of Supreme Court. Advocate is licensed under Nepal Bar Council Exam, which are written examination, oral examinations, and training after the success of Bachelor's Degree in law. ${ }^{27}$ Pleader and Agent are continued from previous process. New mechanism doesn't grant such license. $^{28}$ They should abide code of conduct for legal professional as well. ${ }^{29}$

$24 \quad$ Nepal Bar Association. https://nepalbar.org.np/en/homepage/.

25 Section 17 of Nepal Bar Council Act, 2050: Legal Practitioners to be Registered: (1) A Nepali Citizen with the following qualifications having passed the Legal Practitioner examination and who is not convicted of any criminal offence inflicting moral turpitude shall only be registered as a Legal Practitioner: (a)A person who has worked for at least Five years after having a certificate of Bachelor's Degree in Law as a judge, government advocate, or as Gazetted Officer in the Legal Service or as a teacher of Law; or (b)A person who has practiced as a Pleader (Abhivakta) for Five years and having the Bachelor's Degree in Law; or (c)A person who has practiced as a Pleader for Seven years; or (d)A person having Bachelor's Degree in Law. (2) A Nepali Citizen with the following qualifications, having passed the Legal Practitioner Examination and not convicted of any criminal offence inflicting moral turpitude shall be registered as a pleader until last of Chaitra 2070: (a)A person having the Intermediate Certificate in Law; (b)A person practicing as an Agent (Abhikarta) for a period of Five years.

26 https://nepalbarcouncil.org.np/en/home-page/.

27 Curriculum for Examination for Advocate. https://nepalbarcouncil.org.np/download/\%e0\%a4\%85\%e0\%a4\%a7\%e0\%a4\%bf\%e0\%a4\%b5\%e0\%a4\%9 $5 \%$ e0\%a5\%8d\%e0\%a4\%a4\%e0\%a4\%be-\%e0\%a4\%a4\%e0\%a4\%b9\%e0\%a4\%95\%e0\%a5\%8b$\%$ e0\%a5\%a8\%e0\%a5\%af-\%e0\%a4\%94\%e0\%a4\%82$\%$ e0\%a4\%aa\%e0\%a4\%b0\%e0\%a5\%80\%e0\%a4\%95\%e0\%a5\%8d/.

28 Nepal Bar Council Act, 2050 (1993 AD). https://www.lawcommission.gov.np/en/wpcontent/uploads/2018/10/nepal-bar-council-act-2050-1993.pdf.

29 The Code of Conduct for Legal Practitioners, 2051 (1994). https://nepalbarcouncil.org.np/en/code-ofconduct/. 
Lawyers' participation is expected in every popular movement of Nepal. It makes coordination with International Bar Association, American Bar Association, and Asian Bar association etc. Lawyers are participated in pro bono work, ${ }^{30}$ mediation, arbitration, trademark registration, company registration, project drafting, company secretary, notary public, probe commission, human rights project, NGOs, judicial council, Nepal Bar Association, legal aid committee, Nepal Judicial Academy, law commission, ministry of law, law reform project, High Court, Supreme Court etc. Legal audit concept has been frequently raised but it has not been implemented till this date.

Nepal Notary Public Council Act, 2063 BS (2007 AD) has granted power to Nepal Notary Public Council $^{31}$ to conduct examination for the license of translator after 7 years of practices and other notary public. ${ }^{32}$ Legal Aid Act, 2054 BS (1997 AD) and Arbitration Act, 2055 BS (1999 AD) have also emphasized on the role of legal professionals.

There are frequently cited issues by the legal community in Nepal in terms of lawyer, which are recommending for proper standard of taxation and exemption, transparent fee, timely handling of the case, removal of political personality, domestic and international exposure, supporting to new lawyers, and sufficient continuous legal education etc. These issues are required to reform legal profession in Nepal. It is necessary to establish Lawyer's School for continuous legal education and apprenticeship training to the lawyer and incoming lawyer. Despite it, Nepali legal professional are increasing their qualification both in theory and practice in contemporary time with specialization process.

\section{Case Law of Supreme Court of Nepal}

- Advocate Ram Krishna Nirala vs Commission for the Investigation of Abuse of Authority: If there are ordinary or alternative remedies, a person should seek justice from it. Extraordinary jurisdiction cannot be exercised to the extent that the alternative remedy system exists under prevailing laws. Advocacy fee received for the day of public

Legal Aid Act, 2054. https://www.lawcommission.gov.np/en/wp-content/uploads/2018/10/legal-aid-act2054-1997.pdf.

Nepal Notary Public Council. http://notarypublic.org.np/about-notary/.

Notary Public Act, 2063. https://www.lawcommission.gov.np/en/wp-content/uploads/2018/10/notarypublic-act-2063-2007.pdf. Notary Public Rules, 2063. https://www.lawcommission.gov.np/en/wpcontent/uploads/2018/09/notary-public-rules-2063.pdf. 
holiday from Royal Nepal Airline Corporation has been accepted by the Advocate. So, the amount received as double payment has to be returned. ${ }^{33}$

- Legal Agent Narayan Prasad Koirala vs Syangja District Court: Under Evidence Act, a legal agent has not received a power to make examination and cross examination of witness in the courts. Prevailing law has granted the rights to make defense from the side of the party only to the advocate. So, the cross examination of witness by the legal agent is revoked. ${ }^{34}$

- Pashupati Karki vs Government of Nepal: Legal profession requires certain qualifications, which are implemented without discrimination to similarly situated people. Such prequalification are as prescribed by the law and the policy of the State. The provision of 9 years terms to pleader to participate in the Examination of Bar Council is for the establishment of skill and experiences of them. Such provision of Nepal Bar Council Act cannot be declared unequal. ${ }^{35}$

\section{- Parshuraam Banjade on behalf of Yagyamurti Banjade vs Durga Das Shrestha:} Judge should listen to the party. If the parties are investigated and prosecuted, they must be granted for the legal counsel by the advocate. Advocate provides legal professional service. It is the case of habeas corpus. ${ }^{36}$

\section{Conclusion}

Civil Legal System following country recommends more on academic knowledge whereas Common Legal System following country favors practical knowledge. Most of the countries of the world require extensive clinical training in the form of apprenticeships training for new incoming lawyer i.e. France, Germany, the UK, Japan, China etc. However, Nepal, India, and the USA do not have the provision of compulsory apprenticeship training through Lawyers School. Yet, the methods and quality of legal education varies from country to country. Moreover, bachelor's degree is the minimum qualification to be a legal professional across the globe in contemporary time. It is believed that higher the legal education higher level of research and

\footnotetext{
33 N.K.P. 07 (2061). D. no. 7404. http://nkp.gov.np/full_detail/2916.

34 N.K.P. 9 \& 10 (2058). D.no. 7033. http://nkp.gov.np/full_detail/6544.

35 N.K.P. 9 (2067). D.no. 8455. http://nkp.gov.np/full detail/3422.

36 N.K.P. 1 (2027). D.no. 547. http://nkp.gov.np/full detail/7542.
} 
advocacy skills will be developed. Legal Education is essentially a multi-disciplinary, interdisciplinary and multi-purposive in nature. So that it can develop the value and idealism required for legal professional to strengthen the legal system. Covid-19 pandemic has created crisis even in this sector because of lockdown and related situation.

'The End...' 


\section{For Further Comments:}

Name: Suman Acharya $(\mathrm{PhD})$

Email: sumanacharaya@gmail.com

Date of Written: June 07, 2021

Important Notice: The views, thoughts, and opinions expressed in the text belong solely to the author, and not necessarily to the author's employer, organization, committee or other group or individual. 